\title{
Zúñiga, Claudia, and Wilson Lopez-Lopez, ed. 2021. Political psychology in Latin America. Washington: American Psychological Association. $268 \mathrm{p}$.
}

doi: http://dx.doi.org/10.18543/djhr.2290

The book is part of the Psychology in Latin America series of the American Psychological Association (APA) edited by Judith Gibbons and Patricio Cumsille. The book presents a series of chapters written by Latin American researchers from Argentina, Colombia, Chile, El Salvador and Peru on different topics relevant to political psychology in Latin America. The problem of human rights violations and how to confront them, socio-political conflicts and the building of a culture of democracy and peace are transversal axes of the chapters of this book.

The first chapter, Citizens and democracy: political legitimacy processes in Latin American democracies by Silvina Brussino and Daniela Alonso, analyzes the role of citizens in the legitimacy processes of political systems in the region, describing the theoretical and empirical contributions of Latin American political psychologists. The authors show that explicit support for democracy coexists with a growing discontent regarding the functioning of this political system. Quantitative and qualitative studies confirm that there is support for the democratic system in general, but at the same time, there is little trust in governments and institutions. The perception that corruption is widespread and is a possible factor eroding trust in institutions. Although qualitative studies also show that this perception of widespread corruption of politicians is associated with a justification of transgressions by citizens who see their acts of "petty corruption" as an appropriate response to this context of ineffectiveness of the institutions. Interpersonal trust in general and in institutions is very low -ranging at first between 4 and $20 \%$, for example. This low social capital is accompanied by low political participation. On the other hand, people who mobilize in street protests are characterized by sharing democratic values more strongly, although at the same time they feel more distrust towards the government and institutions, than people who do not mobilize.

The second chapter, Emotions and protests: contributions to political psychology from Latin American research, by Rodrigo Asún and colleagues, analyzes processes associated with the emergence of social movements, and the reasons that lead individuals to participate in political protests. The main findings show that in the same mobilization 
event, different groups of people may experience different emotional constellations at different times. For example, an analysis of the content of twitter messages around a student protest for democratic rights in Mexico showed that anger and indignation predominated at the beginning, pride, distrust and sadness in a second phase, and fear, sadness and hope in the final phase. In a quantitative study (which are in the minority in a context where descriptive qualitative studies predominate), the authors analyzed the emotions felt by the inhabitants of an area in a regionalist protest in Chiloe, Chile. They found through latent class analysis three types of constellation of emotions: $17 \%$ of "proud" who felt only positive emotions, in particular pride. $27 \%$ of "concerned" who felt negative emotions such as worry, anger, sadness and positive emotions such as pride. These two constellations were associated with participation in the protests. A $60 \%$ of the indifferent reported low levels of all types of emotions and did not participate. In general, studies have highlighted the importance of positive emotions, such as hope, for mobilization.

The third chapter is a psychopolitical approach to social inequality in Latin America by Débora Imhoff. Latin America is characterized by great inequality also extended to skin color and ethnicity: Afro-Latin Americans and Indigenous people are more likely to be poor and less likely to finish school or get a formal job. In Latin America, inequality is structural and historical in nature. Thus, despite the decline in inequality observed in recent decades, Latin America remains one of the most unequal regions in the world. The text systematizes the main findings of psycho-political research on social inequality in Latin America, first presenting studies on social inequality perception, which is generally high, although the different indicators are not so strongly associated with each other. Secondly, research oriented to operationalize in the cultural context scales of system justification approach. Meritocracy and a positive view of the economic system decrease the perception of inequality. Third, the research shows that RWA and SDO are psychopolitical variables that contribute to justification of inequality. Finally, suggestions for approaching the problem aimed at those members of civil society and public policy makers interested in contributing to the reduction of social inequality in the region are proposed.

In the fourth chapter, Youth civic engagement: challenges for social cohesion in Latin America, B. Paula Luengo and colleagues examine how civic engagement can support social cohesion. Three studies developed in the Chilean context show how young people learn and exercise their citizenship and how civic engagement can support social cohesion in the school context. The authors conclude that in order to 
improve civic and political commitment of youth, it is essential to have educational programs that seek to promote citizenship capable of strengthening social cohesion.

Chapter five by Camila Salazar-Fernández and José L. Saiz examines the Bias against Indigenous Chileans in a Conflictive Context. This chapter focuses on biases against the Mapuche, Chile's largest indigenous minority group, who face high levels of social exclusion and poverty and are involved in a chronic and asymmetrical conflict with the Chilean state and forestry companies. A systematic review of the literature allows the authors to apply the BIAS stereotype map of Fiske et al. to the case of the Mapuche. A stereotype of low warmth and low competence (hostile, barbaric) is related to a contemptuous biased view of Mapuche, with negative emotions and rejection. While the explicit measure has found a medium low rejection, the implicit measures have found a high level of the rejection of the Mapuche. This stereotype and bias reinforce the conflict between the Mapuche and the Chilean state and non-indigenous groups. A low competence and high warmth (charming little Indian) stereotype is related to a paternalistic bias and view of Mapuche and emotions like pity and compassion, which are reported at medium high level by non-Indigenous Chileans. This stereotype does not increase, but rather maintains the conflict, because it encourages partial and vertical measures, which do not take into account the demands and autonomy of the Mapuche. Although less predominant, there is also a vision of the Mapuche as highly competitive and low in warmth, as a group that takes advantage of the state's social assistance, related to envy. This stereotype and emotion fuels the conflict, because it leads to the rejection of the "unjustified and exaggerated" aid given by the state to the Mapuche. Finally, some evidence shows, that some groups (university students, educated youth) share a positive stereotype of high competence and high warmth towards the Mapuche (Mapuche as national ancestors, brave warriors and patriotic citizens) and absence of negative bias. This stereotype decreases conflict and helps to recognize the Mapuche as legitimate and equal actors. The authors highlight that intergroup biases in conflictive contexts are psychosocial barriers that maintain or increase the conflict, preventing progress toward peaceful coexistence. They emphasize that these barriers can be overcome through interventions aimed at reducing adherence to bias to ennable groups in a society to initiate and continue negotiations, reach agreements, and engage in reconciliation.

Chapter sixth, Psychology of Peace: Findings and Challenges for the Multi-dimensional Transformation of Violent Social Practices, by 
Wilson López-López and colleagues, examines the topic of conflict and reconciliation in Latin American political psychology. The authors emphasize that peace building includes different dimensions such as socio-economic (decrease of inequality), socio-political (reinforcing democracy and facilitating social coexistence), socio-legal (avoiding impunity, reinforcing the legal system and restorative actions), socio-cultural (rejection of violence, social exclusion, and increase of tolerance, gender equality and child rearing), socio-environmental (ecological sustainability). These social transformations are not sufficient if they are not accompanied by structural transformations. Studies that have examined the psychosocial dimension of peace in the context of the Colombian armed conflict are reviewed. With more than 8 million victims registered since 1985, the armed conflict is a central element in Colombian society. This collective experience has led to a loss of empathy, a strong differentiation between them and us, and the justification of the use of violence. Studies conducted in the general population found that some social beliefs, such as the need for security, patriotism and the delegitimization of the adversary are barriers to peace. The meaning attributed to forgiveness and reconciliation includes the rejection of negative emotions, forgetting the offense, guarantees of non-repetition and retribution. Finally, willingness to forgive is low, as is usual in others Latin American studies. $18 \%$ of the Colombian population has been a victim of the conflict. Studies with them have shown that in addition to the aforementioned attributes, victims add to the meaning of forgiveness and reconciliation the non-repetition of violence, restoration and apologies, as well as improved well-being. With respect to ex-combatants, studies report that most feel high levels of reconciliation with those who attacked them in the past. This feeling is lower among ex-guerrillas than among paramilitaries, particularly if they are not integrated into reinsertion experiences and networks. It remains to be seen how the victims experience this satisfactory reconciliation of ex-combatants. This psychosocial perspective is intended as a contribution to peace building both in Colombia and in other places where collective violence has been relevant in society.

In chapter seven, A. Espinosa and colleagues examine The Relationship between Political Ideology and National Identification in Latin America, through a meta-analytic synthesis. A meta-analysis examined the nature of the relationships between national identity, on the one hand, and right-wing authoritarianism (RWA) and social dominance orientation (SDO), on the other, in samples from 11 Latin American countries. The results show that RWA is positively associated 
with the degree of national identification, $r=0.16$, suggesting that conservative authoritarian beliefs and values fuel national cohesion. The fixed model shows that the positive associations between RWA and degree of national identification are heterogeneous. The percentage of indigenous/afro-descendent participants significantly moderated the strength of the positive association between RWA and national identification. Significant positive associations between RWA and national identification can be observed in 'white mestizo' countries, such as Chile, Colombia, Costa Rica and Venezuela, but not in countries with a higher Afro-Latin American or indigenous populations, such as Bolivia, Brazil, and Mexico. In the first nations, where the imagined community is relatively "Euro-American" (or white mestizo) authoritarianism enhances national identification. These national narratives minimize the presence and contribution of indigenous and Afro-Latin American populations, while emphasizing that of the Spanish and mestizo population.

The relationship between SDO and degree of national identification using a fixed model indicates a negative association with a small effect size, $r=-.084$. Meta-regression using the proportional percentage of indigenous/Afro-American participants shows that the higher the proportion of nonmestizo/white the population, the more negative the association between SDO and degree of national of identification. The negative association between SDO and degree of national identification is significant in countries such as Bolivia, Brazil, Ecuador, Mexico and Peru and non-significant in the "whiter/mestizo" nations. Globally, the results suggest that SDO is related to lower levels of national identification in nations with higher diversity and greater social distance between ethnic groups such as Bolivia, Brazil, Ecuador, Mexico and Peru. In these nations, the high social salience of low-status indigenous and Afro-Americans has a negative impact on the relative status of national category among citizens, thereby facilitating a process of social distancing in young adults belonging to the middle and upper classes.

In chapter 8, Political Communication and Ideology, Idaly Barreto and Iván Felipe Medina-Arboleda address the issue of political communication. The authors present two studies on presidential speeches from five Latin American countries. The first study focuses on the microanalysis of discourse with the purpose of identifying the belief systems exhibited in the presidential speeches. The second study analyzes the macro-level contexts of the speeches in terms of economic and political indicators for each country. The last two chapters reflect on a topic that has had an important development in 
Latin America: collective memory studies. Chapter nine, Memory as a Political Action: Reflections From Postdictatorial Chile by María José Reyes and colleagues, presents an ethnographic case study to shed light on the construction and transmission of memories in La Legua, an urban-peripheral community characterized by historical resistance to the Chilean dictatorship and by serious ongoing problems with social violence. The authors problematize one of the assumptions of Latin American political psychology: that social memory is a practice of resistance in itself. They also discuss the uses of memory in state policies, which generate the configuration of a single official memory and identity that does not correspond to the multiple identifications and collective memories of the members of the members of this community. In Chapter ten, Arguing for a Liberation Psychology, Mauricio Gaborit discusses the nature of liberation psychology and draws attention to some of its most outstanding contributions. He presents research on historical memory in postwar El Salvador that explores the psychosocial importance of the memory of collective trauma and the role it plays in mental health.

To close the book, the Conclusion synthesizes the cross-cutting themes addressed in this work, identifies the book's main limitations, and proposes some future directions for Latin American political psychology.

The book is highly recommended for those interested in sociopolitical problems in general and of Latin America in particular, as well as for people interested in confronting and overcoming conflicts and inequalities, particularly human rights violations. The price is very affordable, and the APA distributes it very efficiently and quickly by regular mail. ${ }^{1}$ We highly recommend the purchase and reading of this text.

Dario Páez

Department of Social Psychology University of the Basque Country

1 It can be purchased at the following link: https://www.apa.org/pubs/books/ political-psychology-latin-america 


\section{Copyright}

Deusto Journal of Human Rights / Revista Deusto de Derechos Humanos is an Open Access journal; which means that it is free for full and immediate access, reading, search, download, distribution, and reuse in any medium only for non-commercial purposes and in accordance with any applicable copyright legislation, without prior permission from the copyright holder (University of Deusto) or the author; provided the original work and publication source are properly cited (Issue number, year, pages and DOI if applicable) and any changes to the original are clearly indicated. Any other use of its content in any medium or format, now known or developed in the future, requires prior written permission of the copyright holder.

\section{Derechos de autoría}

Deusto Journal of Human Rights / Revista Deusto de Derechos Humanos es una revista de Acceso Abierto; lo que significa que es de libre acceso en su integridad inmediatamente después de la publicación de cada número. Se permite su lectura, la búsqueda, descarga, distribución y reutilización en cualquier tipo de soporte sólo para fines no comerciales y según lo previsto por la ley; sin la previa autorización de la Editorial (Universidad de Deusto) o la persona autora, siempre que la obra original sea debidamente citada (número, año, páginas y DOI si procede) y cualquier cambio en el original esté claramente indicado. Cualquier otro uso de su contenido en cualquier medio o formato, ahora conocido o desarrollado en el futuro, requiere el permiso previo por escrito de la persona titular de los derechos de autoría. 